\title{
MAKE IN INDIA - PROSPECTS FOR EMPLOYMENT GENERATION
}

\section{JASMIN}

Assistant Professor, Jesus and Mary College \& Ph.D. Scholar, Jawaharlal Nehru University, New Delhi, India

\begin{abstract}
India has been witnessing a serious problem with employment generation. "Make in India" campaign aims at transforming India into a global manufacturing hub and generate enough employment. However, the current status of the manufacturing sector presents several impediments in making Make in India a success. Overtime, the absorptive capacity of the sector has tended to decline, which poses serious doubts about the achievability of the aims of the campaign. In such a case exclusive focus on the manufacturing sector looks like a faulty strategy. The paper argues that identifying appropriate manufacturing goods and services that can generate enough employment and usher in growth is a better strategy. Along with this identification Skilling and educating India has become imperative, to make the workforce ready for productive employment opportunities.

KEYWORDS: Make in India, Skill India, Manufacturing Sector, Informalisation, Low-Productivity Sectors \& Agrarian Crisis
\end{abstract}

Received: Jul 06, 2017; Accepted: Jul 28, 2017; Published: Aug 03, 2017; Paper Id.: IJECRAUG201711

\section{INTRODUCTION}

India has been witnessing a serious problem with employment generation. Impressive growth rate registered by the country, over the last few decades, has failed to reflect a concomitant improvement on the employment generation front. The Dismal performance of the manufacturing sector has a lot to explain as to why inclusive growth remains a far-fetched dream for India. The skewed distribution of the returns to growth in favor of the rich and limited employment generation point towards an unsustainable growth trajectory. These two issues are somewhere linked to the fact that the manufacturing sector has failed to increase its contribution to the GDP and at the same time its performance has been disappointing on the employment creation front. The manufacturing sector has been perceived to be the key to economic growth, since the time of Industrial Revolution in the 18th century. The development theory states that the growth trajectory for any nation involves siphoning off the resources from the agricultural sector to expand the manufacturing sector. However, in the recent years, this role of the manufacturing sector has become dubious. India has made a leap from agriculture to services, trying to match its position with the advanced countries where the service sector is dominant now.

This serves as a background for the "Make in India" campaign; the goal is to transform India into a global manufacturing hub and generate enough employment. The campaign perceives raising the global competitiveness of the Indian manufacturing sector as an imperative to igniting long-term growth. The target is to elevate the manufacturing sector growth to $12-14 \%$ per annum over the medium term and generate 100 million additional jobs by 2022 in the sector. The program includes major new initiatives designed to facilitate investment, foster innovation, protect intellectual property, and build best-in-class manufacturing infrastructure. Norms have been eased in major sectors to attract foreign direct investment. 
While "Make in India" has invited a lot of support, there are economists who advise that sticking to the service sector and generating jobs there is a better move, Green (2014). It is the high-quality jobs that India needs to generate. Amirapu and Subramaniam (2014) emphasize that it is the formal manufacturing sector which is characterized by high productivity and dynamism, not the informal sector. This clearly implies that the policies should be fabricatedto expand the formal sector. However, all this seems more like a challenge to the manufacturing sector. The feasibility of such an approach is under question, given the fact that India is on the road to premature deindustrialization. India has a huge unorganized sector which has been absorbing workers who move away from the agrarian sector in search of better opportunities. Sadly, the unorganized sector has only got low quality, casual jobs to offer, with hardly any stability of tenure. This sector, as well as the buffer available in the agriculture sector, has played a great role in real wage stagnation. Unfortunately, this easy availability has encouraged the use of contractual employees even in the organized sector. At the same time, technological up-gradation and a switch to capital intensive techniques have reduced the labor intensity in the manufacturing sector, making the prospects for employment generation bleaker.

The aim of this paper is to assess the viability of the campaign and its prospective contribution to inclusive growth. This will necessarily involve presenting the historical and current status of manufacturing sector domestically and at the global level, reasons as to why employment generation and growth have been abysmal. India's trade in manufactured products has grown significantly. Still, it remains far from becoming a global manufacturing hub. Thereforeit is important to identify subsectors in the manufacturing as well as the services sector with good potential for employment generation. India's comparative advantage, its position in global product sharing and possible future developments on this front has important implications regarding the exports. The labor intensity, in terms of the composition of the goods and services, produced also has repercussions on the status of employment. Hence it becomes imperative to analyze what all forms of labor-saving technical changes have taken place. Taking stock of the previous policies formulated with the motive to give employment in various sectors a boost, as well as the minimum wage laws, will help identify improvements that have taken place in the past and what needs to be charted out for the future. For instance, programs with the objective of vocationally training and helping the workers with skill development could potentially be a significant step in this regard.

Competitiveness regarding lower costs gives the edge to the exporting activity of any nation, how is the production kept competitive also needs to be analyzed. Labor costs in manufacturing are already low and bringing them down further will be counter-productive. This not only means compromising on the livelihood of the workers, but also making the growth trajectory unsustainable. Make in India is a campaign that is being administered at the central level, state level disparities can present a great number of problems in implementing it. For instance, states at different stages of development, experiencing different thresholds of poverty, inequality, and phases of demographic transition could present multiple challenges. This calls for state specific policies to achieve the desired target.

India needs a comprehensive policy framework to generate quality employment and growth.

\section{LITERATURE SURVEY}

This section begins with a discussion on important theories which will place the discussion in a better perspective. Lewis (1954) and Fei-Ranis (1961) discuss dualism. Lewis (1954) discusses the case of developing countries, with a modern sector and a subsistence sector. The development of such economies involves the movement of labor, available in the subsistence sector as an unlimited supply, to the industrial sector at fixed wages. This transition continues till the surplus labor is absorbed. Fei and Ranis formalized the Lewis model. Harris-Todaro (1970) explained the rural-urban 
migration and the phenomenon of the existence of the informal sector. A plethora of studies explains India's jobless growth using the kaldorianframework. Dasgupta and Singh (2006) use Kaldor's theory to explain the job problem in India. They argue that the Indian economy has the largest size of labor force located in agriculture andinformal activities; there is widespread disguised unemployment, which represents the available labor force for the manufacturing sector. Moreover, informal, casual and daily laborers constitute the majority of Indian workers in rural areas, where most of the poverty is concentrated. It follows that agricultural surplus over self-consumption is low and the demand for industrial products coming from agriculture could be insufficient to ensure a further growth of manufacturing production accompanied by the efficient allocation of disguised laborers in organized industrial activities. This leads to the expansion of the informal economy, which absorbs the mass of rural workers migrating to the urban centers and which could push India away from its trajectory from a dualistic to a modern economy (Dasgupta\& Singh, 2006).

This work derives its motivation from the existing research and reports not only on the campaign but a plethora of studies on the status of employment in India and the sad state of employment generation. This section presents a survey of the research followed to prepare this piece of work.

Green (2014), discusses how realistic a strategy, the "Make in India" campaign is. He highlights the factthat it is the formal sector, which should be the mainstay for employment generation. According to Green, services, lack the potential to generate high-quality jobs, increasing the employment elasticity for this sector is a challenge. The formal manufacturing sector, on the other hand, has not been able to realize its potential due to an adverse policy regime. He, then argues, for a relatively supportive policy framework for the same. The paper describes significant reforms in this regard, namely, easing labor regulation, facilitation of land acquisition, improvement of the business-government interface, provision of public goods, and institutional reform.

Anand et al. (2015), analyzes India's exports by the technological content, quality, sophistication, and complexity of the export basket and identifies exports that can make "Make in India" successful. The paper identifies five key areas for policy action, aiming at making India a global manufacturing hub. They suggest reducing the trade costs, further liberalizing foreign direct investment, improving infrastructure, encouraging skill enhancement and ensuring human resource development, infusing greater flexibility in the labor markets, last of all creating an environment receptive to technological up-gradation and innovation. The paper concludes that India can benefit by increasing the quality of its high and medium technology intensive manufacturing exports. Also, the country can benefit out of the sophistication it has achieved in its services. Indian service exports are comparable to international standards, further development, and diversification of these services, could turn them into lucrative exports. This could also help meet the employment generation goal.

Rao and Dhar (2016), looks at the magnitude and nature of FDI inflows into India since the Make in India program has been initiated. The paper mentions that the campaign has not been able to attract FDI in the focus sectors. The nature of inflows needs to be examined with caution ${ }^{1}$.

\footnotetext{
${ }^{1}$ According to Rao and Dhar (2016), the reported investments should be examined from the points of (i) adding fresh domestic production capacities (including meaningful indigenisation), (ii) net addition to capital instead of round-tripping of funds remitted abroad on one pretext or the other, (iii) the monetary value of all the incentives and exemptions availed and (iv) last but not the least, delayed reporting and gross inaccuracies. Acquisitions and disinvestments (not to speak of outward FDI) undermine the contribution of the inflows to new capacity creation in the economy.
} 
Papola (2007), presents an account of the trends in employment during the period 1973 $\square 2000$.The paper indicates how the higher rate of economic growth experienced by India during this period, failed to bring about an improvement on the employment front. He also highlights structural and qualitative dimensions of employment in India, for instance, a slow change in the sectoral composition of employment, thedominance of self $\square$ employment and increase in the share of the casual workers, a growing unorganized sector, stagnation and decline in the organized sector employment. The paper also mentions how the quality of employment has deteriorated in the recent times.

Sasikumar and Thimothy (2013), Shaw (2013) give an overview of the employment trends based on NSSO's 68th round. Both the studies highlight an improvement on the employment front, in terms of revival in growth. Sasikumar and Thimothy (2013), mention that manufacturing employment has stagnated, theyemphasize on the much-needed policy action to meet the challenge posed by the demographic bulge. Low skill and increasing informality in the workforce are the two problems that ask for a remedy.

Shaw (2013), presents evidence for a rebound in employment growth. However, his analysis shows that the average growth in employment between 2004-05 and 2011-12 remained as low as 2.5 million per year.

Economic Survey (2014-15), states that emphasis should be laid on skilling India so that the future generations could benefit. Focus on education and skill development will ensure that future generations are employable and can be absorbed into quality employment.

Kapoor (2014), examines the factors holding back the growth of output and employment in the manufacturing sector. The paper discusses how the recent economic growth has benefited industries which are relatively capital intensiveand rely on skilled workers; the unskilled workforce continues to suffer. She points out that the increasing informalization of the organized sector has allowed low productivity activities dominate employment in India. The paper, emphasizes the importance of state-level policies in igniting the growth of the manufacturing sector and accelerating employment generation.

Srija \& Shirke (2014), highlights predominance of informal employment in India. They state that informalization is a challenge which cannot be easily surmounted through labor reforms. The solution is to create an environment which encourages the micro and small scale enterprises to register and realize the benefits of becoming a part of the formal economy.

This study on the "Make in India" campaign utilizes studies mentioned above to assess the trends in employment and analyzing the role of the manufacturing sector in employment creation.

\section{Job Opportunities and the Nature of Employment in India}

The inclusion of the individuals in the process of growth cannot be imagined without providing them with adequate employment opportunities. Unfortunately, India continues to struggle with a jobs problem. According to the $68^{\text {th }}$ NSSO round, as pointed out by Shaw (2013), in 2011-12, 36.4\% of the population in India was actively involved in the labor force according to the UPS data, as per the UPSS estimates over nine million persons found employment between 2009-10 and 2011-12 $2^{2}$. Figure 1 in the appendix shares the trends in the unemployment rate in India ${ }^{3}$. The unemployment

\footnotetext{
${ }^{2}$ On a yearly basis the growth in employment in terms of UPSS works out to 4.68 million per year between 2009-10 and 2011-12. But in terms of UPS it was much lower, only 1.73 million per year
} 
rate in India has been lower than that of developed nations. However, in absolute terms, the unemployed in India add up to a significant number. For instance, during 2009-10 to 2011-12, the number of unemployed rose from 9.8 million to 10.8 million regardingas per UPSS, while there was a decline in the number of unemployed from 28 million to 24.7 million as per the CDS criterion. There is a difference between unemployment and underemployment. Bureau of labor statistics, United States, defines underemployment as a statistic that includes over and above the unemployed, the people who are no longer looking for work and the involuntary part-time workers, the people who could not find employment of full-time nature despite their capabilities. The CDS measure includes both unemployment and underemployment. As illustrated by the figure underemployment is a graver problem for India. A very important exercise is to study unemployment in conjunction with poverty. A large proportion of employed in India, work at abysmally low levels of wages and income. Henceforth, the goal should not only be to generate more jobs, but also to provide better income and working conditions to the workers.

As Table 1 in the appendix, indicates the share of the workforce in the primary sector has declined from $58.5 \%$ in 2004-05 to 48.9\% in 2011-12, while the share of the workforce in the secondary and services sector has risen during the same period. There is a story behind these figures, disappointing trends that display sluggish absorption of people in the labor force, an absorption which is primarily informal in nature.

Tables 2 and 3 help us draw important inferences about the informality which is prevalent in all the sectors of the economy. The organized sector which is expected to generate employment opportunities of the formal nature is also increasingly relying on casual and informal labor. According to the statistics presented by Srija \& Shirke (2014), informal employment, which was about $92.73 \%$ in $2004-05$, has come down by a minuscule figure to $91.86 \%$. The numbers itself show the nature of the growth in employment, India is witnessing. The shrinkage in the employment in agriculture has found a way in terms ofan expansion in the other non-agriculture sector, but most of it is in the informal segment.

This huge pool of labor in the agriculture sector acts as a buffer for the non-agriculture sectors to draw from. The conditions created in the agriculture sector, the real wage stagnation and the large labor reserve, have definitely supported a rise in the surplus incomes. The surplus incomes of the secondary and tertiary sector have grown however there hasn't been enough growth in the employment opportunities so that the benefits could trickle down to the labor. Low wages and a bleak potential for any improvement in the job quality in the organized sector says volumes about how miserable the condition would be in the informal sector.

Mazumdar (2014) explains that the conditions for a strong wage-depressing tendency in the Indian economy and the heightened informalisation and casualisation of work were set up among other things by the onset of a deep-rooted agrarian crisis since the mid-1990s. Stagnation in agriculture, increasing production and marketing risks in a liberalized trade and market regime, institutional vacuum and lack of alternative livelihood opportunities were the root cause of this crisis. The crisis impacted small and marginal farmers the most, support systems to farming weakened, public investments in agriculture declined, and institutions were of no help. The inability to come up with technologies that could reduce cost, the rising input pricesmade cultivation un-remunerative. Since large segments of the agriculture-dependent population were hit by a fall in profitability of agricultural activity and an increasing burden of debt, more and more people were

\footnotetext{
${ }^{3}$ UPSS: Usual Principal and Subsidiary Status includes, besides UPS, those available but unable to find work on a subsidiary basis, during a year. CDS: Current Daily Status measures unemployment in terms of person days of unemployment of all persons in the labour force during the reference week.
} 
driven out of that sector to seek work in other activities. Though much of India's working population remains rural, there has been a steep decline in the share of agricultural in total employment since $1991^{4}$. The push out of agriculture has resulted in the swelling of an already vast labour pool which the expansion process outside agriculture could then draw on without that process exerting any upward pressure on wage levels. The share of informal employment has increased in the industry over time. Surprisingly the reliance of organized service sector on informal labour has grown. In nonmanufacturing sector, which includes the construction sector, there is an increase in employment in both the organized and unorganized sector as well as in the formal and informal sector. However, the share of informal employment is higher. Construction has become a mainstay for the migrant labor (Mazumdar, 2014).

Apart from employing labor informally, the growth of the industry has also been subsisted by the use of cheap labor for supplementary activities. This kind of expansion of employment accompanying rapid corporate sector growth has not adequate to eliminate the excess labor availability.

\section{India's Structural Evolution}

India's job's problem is very well illustrated in figure 2. Agriculture continues to lose its ground in favor of services when it comes to GDP contribution. Also, this sector employs the largest share of the workforce. Industry, i.e. manufacturing and non-manufacturing taken together have contributed abysmally to both the spheres. Services, enjoying the lion's share of GDP, hold roughly $27 \%$ of the workforce.

Green (2014) compares the Indian case of structural evolution with the global transformation. He mentions that the Indian experience is of the kind, not witnessed elsewhere. The high-income countries of the current times, moved from intensive dependence on agriculture sector to large-scale manufacturing, in terms of employment and GDP. Service sector domination came later with high per-capita income levels. Even the successful developing countries had experiencedlargescale industrialization before the services took over. Looking at the group of developing countries over the recent years, the share of employment in the industry continued to grow while agriculture employed fewer workers. The share of the service sector grew fastest, however. Developed countries have lost manufacturing jobs overall as their economies automate further and rely on services for employment. In terms of GDP, the service sector in developing countries grew fastest, gaining output share, while agriculture fell behind. The industry hit the middle, maintaining a constant share of GDP. In developed countries industrial output actually shrank, indicating their post-industrial status.

For India, on the other hand, industry has added jobs faster than even services. Although, most of this job generation in the industry can be attributed to construction rather than manufacturing. A further distinction for India is that it saw growth in industry's share of GDP, mostly due to growth in manufacturing. The service sector share of GDP grew faster, furthering India's service sector dominance.

Figure 3 and Table 4 indicate the growth in employment and GDP for various sub-sectors in theeconomy during the period 2004-05 to 2011-12. The aim is to recognize the sectors that have a greater potential to generate Jobs. Ideally, a sector adding a greater number of employees for every percentage increase in GDP should be targeted, as far as policy making is concerned, with an objective to generate employment. At the same time, the exercise to list down the sectors that could potentially drive the growth requires looking at the labor productivity. Productivity means getting more done with

\footnotetext{
${ }^{4}$ Mazumdar (2014) further mentions that in the early 1990s, over 61 per cent of the workforce was engaged in agricultural activities as per the NSS data. In 2011-12, however, the proportion was less than half.
} 
fewer workers, so related to high productivity is a limited impact on employment. The bubble sizes in Figure 4 indicate that the high-productivity sectors, mainly services do not employ nearly as many workers as the low-productivity sectors. However, it doesn't mean that the labor force should be allowed to stay stuck in the low productivity sectors, with poor job opportunities.

Figures 3 and 4 together indicate that a major proportion of the Indian labor force is trapped in low productivity agriculture; the sector contributes little to the GDP. There is a need to pull these workers out and shift them to high productive sectors, where they could expect better wages and employment conditions. Opportunities need to be created in the formal manufacturing and services sector, with an emphasis on educating and providing skills to make the workforce suitable for these job opportunities.

It has been debated that the rapidly growing high-skilled service sector can only provide employment to a very small percentage of the growing labor force. However, there is potential for employment generation. According to the World Klems database, which figure 4 utilizes, business services, which can be put in the category of modern service, has an employment growth rate of $21.3 \%$ and the corresponding productivity growth rate is $5.72 \%$.Business services include a gamut of activities: computer and related activities in the private sector, Legal Activities, Accounting, Book-keeping and related activities as well as researchin development. Similarly, Other Services which includes Real Estate Activities; Renting of Machinery and Equipment and Other Business Activities; Other Community, Social and Personal Services, Private Household with Employed Persons, has shown a high employment growth relative to productivity improvement. Also, the growth in employment in the other sub-sectors of services, for instance, financial services, education, hospitality, health and social work etc. is not very disappointing. These sectors can be targeted for adequate policy measures, to expand their workforce size.

According to the tables 4 and 5, certain sub-sectors in the manufacturing segment have shown impressive employment growth rate, for instance: manufacture of rubber and plastic products, other non-metallic mineral products, basic metals and fabricated metal products, machinery production, electrical and optical equipment, transport equipment and manufacturing, n.e.c. These sectors can be tapped for employment generation. It is important to study the formal and informal components of the manufacturing sector together. Green (2014) presents figures on the contribution to employment and GDP by the formal and informal manufacturing. The distribution of employment across the formal and informal manufacturing is $19 \%$ and $81 \%$ respectively; figures for the contribution to value added are $71 \%$ and $29 \%$ respectively. The figures suggest that the formal manufacturing is far more productive. He also mentions that formal manufacturing has the potential to generate quality employment, as it has registered an impressive rate of employment growth in the last decade. The challenges impeding this development are, the formal sector being too small and increasing capital intensiveness of production methods.

On these parameters, construction, a non-manufacturing sub-sector, is the only one that has been contributing to employment massively. But as argued earlier, this employment is not qualitative. Informality, as shown in Table 6, is pervasive in all sectors and growing by considerable amounts. So even if the sector is contributing a greater amount to employment compared to GDP, it doesn't necessitate generation of quality employment.

A lot can be illustrated about the nature of job opportunities using data on the status of employment. Table 7 shares these estimates. 
Casualisation of the workforce or in other words, using contractual labor is a problem too. Self-employed and casual workers constitute a major fraction of employment in most of the sub sectors. Contractual employment has made its way to most of the sectors, with a large number of the sectors registering a rise in this proportion. Certainly, a casual employee does not have any stability of tenure, to make matters worse; the wages that they get are lower than those of the regular workers. For instance, as per the 68thNSSO round, average wage and salary earnings per day received by employees according to usual status engaged in AGEGC and non-agriculture sectors taken together for all enterprises was Rs.401.30 for regular or the salaried workers, while it was Rs.154.72 for the casual laborers.

At the same time, this data has a positive story to tell. The manufacturing and service sub-sectors that have registered impressive rate of growth in employment (mentioned above) have also registered a rise in the share of regular workers.

It needs to be reiterated that informalization needs to be reduced.

\section{Manufacturing Sector}

Lack of employment opportunities, a growing informal sector is not all. The data for Indian manufacturing sector reveals that workers haven't been able to reap the benefits of economic growth. Worker wages have seen their income share falling in the net value added even as the share of profits has spiraled. 2001-02 onwards the divergence becomes glaringly visible. This pattern of functional distribution of income has become a global trend. Also, empirical evidence indicates that the real wage growth has languished behind real productivity improvement.

A decline in the share of wages in the net value added alongside the real productivity growth outstripping the real wage growth indicates that the workers are certainly not benefitting from the growth in productivity. On the contrary, the gains in productivity are being divertedin favour of profit earners.

Increasing mechanization has led to high growth in productivity across industries. With rising mechanization, workers need to upgrade and enhance their skills, which should ideally translate into higher wages. The rising share of profits reflects that the benefits of growing productivity are being captured by the capitalists. The Dismal performance exhibited by manufacturing sector on the employment front and the compression of the wage share depend on a lot many factors:

- Increased mechanization

- Informalisation

- Contractualisation

- Union labor strength

- $\quad$ Role of minimum wage laws

- Employment programs

- Compression of wages amidst rising costs of other factor inputs to maintain competitiveness

- $\quad$ The ability to set high markups

The factors listed above have a great contribution in affecting the current trends. 


\section{Mechanization}

Capital deepening i.e. a rise in the capital to labor ratio, means replacement of workers by machines. Substituting away from labor has strong implications for the worker wages. The capital intensity of manufacturing has increased over the years. The rise in capital intensity needs to be analyzed in conjunction with growth in labor productivity. Roy (2012) mentions that the growth in capital intensity in the Indian manufacturing sector is strongly correlated with growth in labor productivity, the benefits of which are getting sidelined by the profit earners. He also mentions that the share of workers employed in the manufacturing sector is on a decline and at the same time increasing use of technology might have resulted in a rise in the number of salaried workers, thereby changing the composition of the workforce. It has also been noted that apart from increasing mechanization of the existing industries contributing to wage compression, the emergence of new industries like petrochemicals and metals that are naturally more capital intensive has further added to the pressure.

\section{Informalisation}

Not just mechanization of the existing industries, there has also been a shift in labour-intensive industries such as jute to the informal segment, which has compressed wages in the formal sector.

\section{Contractualisation}

A growing body of evidence indicates a huge inflow of contract labor ready to work for low wages. In fact,informalization of labor-intensive industries and growing contractual hiring of laborisinterrelated. Goldar and Aggarwal (2010) point out that since the 1980s, there has been increasing informalization of industrial labor in India. This process has taken place in two forms, firstly, there has been a continuous rise in the share of unorganized sector employment in the manufacturing sector, and various subsectors of the organized manufacturing sector are sliding to the informal sector owing to a massive use of contractual and informal workers. Das et al. (2015) furnish a very important fact that the share of the workers category in total persons engaged has remained remarkably stable (76.25 per cent in 2000-01, 76.69 per cent in 2006-07, and 77.61 per cent in 2011-12), but the share of contract workers in total workers engaged has been on a continuous rise from 21.31 per cent in 2000-01 to 30.37 per cent in 2006-07 and further to 34.61 per cent in 2011-12.This indicates that there has been a growing preference for contractual workers.

\section{Union Labour Strength}

Das et al. (2015)highlight the role of decline in labor strength as a factor affecting a fall in labor income share. The paper mentions that the union power has displayed a secular decline starting in the 1980s. The important indicators of union strength show a downfall, starting in the 1980s and accelerating in the 1990s. There is no evidence of deterioration in industrial relations as captured by the absence of a strong trend in man-days lost due to industrial disputes as a proportion of man-days worked over the whole of the 1980s. Second, union density declined from 45 per cent in the late 1970s to about 30 per cent in the late 1980s, which further declined in the 1990s. Third, the proportion of man-days lost due to strike started to fall in the 1980s, and the decline accelerated sharply in the 1990s. (Nagaraj, 1994; Dutt, 2003). Even verbal support for labor has declined in the 1990s as the formal private sector workers have become politically weak (Nagaraj, 2002). Furthermore, several states have relaxed the provision of enforcement of labor laws leading to flexible practices at the ground level. 


\section{The Role of Minimum Wage Laws}

There is a prevalent wage setting system in India, whereby the Wage Boards and Pay Commissions generally sets wages in the public sector, which in turn sets the benchmark for private sector wages (Dutta, 2007). Wages are often set at above market clearing levels despite being a surplus labor in the economy. The downward pressure on wages is mitigated by labor market imperfections such as the prevalence of monopsonisticunions and minimum wages stipulated by law, which particularly applies to the public sector, where government employees are largely unionized, assured of life-time employment and face very little risk of being fired (Dutt, 2003). While the presence of unions and minimum wage laws has resulted in wage inflexibility in the formal private sector (Deshpande et al., 2004, and Sharma, 2006), legally guaranteed minimum wages have failed to impact the wages in the informal sector due to weak enforcement, irregular revisions, inadequacy or absence of proper indexation to inflation and absence of trade unions (Dutt, 2003).

\section{Employment Programmes}

India needs a comprehensive policy framework to generate quality employment and growth. Encouraging skill development, recognizing the appropriate subsectors for export and trying to absorb the informal employees into better employment opportunities should be the mainstay of policy. Given the employment situation in the country, various employment generation programs have been announced in the past. There have been programs aimed at generating employment and ensuring minimum livelihood in the rural areas. At the same time, schemes at the level of micro and small enterprises have also been formulated with a special focus on boosting manufacturing employment. Such programs could play a significant role not only in a sense, that there will be more jobs but also in terms of ensuring a secure livelihood for the workers at the bottom most layer, i.e. the rural workers. Unfortunately, programs like MNREGA have failed to achieve a satisfactory remuneration for the rural workers, who remain dissatisfied with their incomes and stay on a constant look out for relatively better options in the informal sector.

Advocates of the program say that MNREGA has brought about a rise in the real wages in the rural sector. Academicians also strongly support the idea of a rise in the wages of casual workers due to MNREGA, a rise in the band of $4 \%$ to $8 \%$. Mahajan (2012) analyzes the impact of MNREGA on the rural wages. Table 6 shares the data on the rising real wages, for male and female agriculture workers across the major Indian states for the periods, 1999-2004 and 2004-2009. 2004-2009 is the period in which MNREGA was implemented in India with all the districts covered by 2008-2009. As Table 8 shows, annual real wage growth rate for men working in agriculture was $3.1 \%$ in the latter period compared with just $1.8 \%$ in the previous period. The difference is even starker for women at 5\% annual growth for 2004-2009 and a meager 1.2\% for 1999-2004. But these figures cannot be analyzed in isolation. Ther real wage growth should be studied along with the growth in productivity. Mahajan (2012) uses growth in yield rates over time as an indicator of productivity in agriculture. Table 8 also shows the growth in athree-year average of food-grain (cereals and pulses) yields. While the food-grain yield registered an increase of $2.5 \%$ per year in 2004-2009, it was as low as $0.1 \%$ per year during the years, 1999-2004. It is important to understand that if the productivity growth outstrips the real wage growth, the wage share of the workers is likely to fall. This analysis highlights the importance of productivity increases.

The net increase in men's agricultural wages, which is obtained by subtracting the food-grain yield growth rate from real wage growth rate stands at 1.7\% for the period 1999-2004 and 0.6\% for 2004-2009. Thus, 2004-2009 witnessed a lower rate of increase in agricultural wages compared to the previous period, once the growth rate in yield is taken into account. The real productive wages for the females for the two periods stand at 1.1 and $2.5 \%$ respectively. Hence the 
wages in the rural sector have grown at a meagerrate, and this is a major explanation as to why there is a growing divide between the rich and the poor. Low wages in the rural sector also explain why the wages are so low in the informal sector, why is it that the economy has not been able to exhaust its unlimited supply of labor. Theabove-listed factors have played a significant role in maintaining a condition of sclerosis in the Indian Manufacturing Sector. The degree of impact of each one of these might differ across the sub-sectors.

\section{Labour Saving Technical Change}

Evidence for increasing capital intensity of the production processes in the Indian manufacturingsector is already well documented in the existing research. Labour saving technological change has been seen as the main factor behind the falling labour-intensity of the manufacturing products and the consequent employment problem. The situation poses a danger because the capital to labor ratio has been rising across industries, i.e. not just the capital intensive industries but also the labor intensive industries. Kapoor (2014) presents data on the growth in capital intensity of production. Table 9, confirms rising capital intensity in labor-intensive industries too which has repercussion for the distribution of value added into profits and wages as well. Of the labor-intensive industries, only manufacturing n.e.c, manufacture of furniture, Manufacture of medical, precision, optical instruments watches and clocks exhibit adecline in capital intensity.

Sen and Das (2014) also identify labor intensive industries based on labor to capital ratio. The paper confirms the trend of risingin capital intensity across Industries. They mention that the overall employment elasticity of manufacturing can increase, even with declining labor intensity, if there is a rise in the share of labour-intensive sectors in total manufacturing. However, this has not happened in India.Using data from Sen\& Das (2014), Table 10 shows that the laborintensive industries haven't become more employment intensive, given the removal of industrial licensing and dereservation and may be linked to restrictive labor laws. It is widely believed that India's rigid labor regulations and employment protection legislation have reduced the incentive of firms to hire workers on permanent contracts and pushed them towards more capital-intensive modes of production. However, as pointed by Sen \& Das (2014) stringent labor regulations might be able to explain the level of laborintensity but to explain the decreasing labor intensity over time, labor regulations would need to have become tighter over time. Since this has not happened in theabsence of pro-worker legislation for the last two decades, they attribute the increasing capital intensity to increases in the ratio of real wage rate to the rental price of capital. This, in turn, is aresult of a fall in the relative price of capital goods, driven by trade reforms and falling import tariffs on capital goods over time.

\section{Inter-State Disparities}

The inter-state disparities make the Indian manufacturing experience unique in itself. These disparities are likely to act as hurdles in successful implementation of the campaign. The states differ regarding the stage of demographic transition they are at, the level of infrastructure development, the flexibility of labor laws, the level of industrialization, etc.

Manufacturing is the main focus of the Make in India campaign. The fact that the states are different levels of industrialization and a general trend of pre-mature deindustrialization exhibited by the economy poses doubts on the feasibility of such a campaign. Amirapu and Subramanian (2014) highlight the disparity in the performance of states on the manufacturing front. They state that Gujarat, Maharashtra and Tamil Nadu are the few states which could achieve a high share of manufacturing sector in the GDP. In all the other states, manufacturing is now on a decline, infact, even in the states that could not even industrialize effectively. 
Table 11, shows projected labor force in India in the year 2026. Krishnamurty and Kumar (2015) give these projections. They project the labor force to grow at around $1.86 \%$ annually compared to $1 \%$ annual growth in population during the period 2012 to 2026 . They argue that the older labor force in the bracket 30-59 years will grow at a higher rate compared to the young labor force. These willpresent problems regarding training and skill the labor force for purposeful employment. States will differ in their contribution to the labor force; Bihar, Jharkhand, and Rajasthan are expected to witness the rapidgrowth of the young labor force. A uniform employment policy for all states has little chance to reap benefits. Hence, a national campaign might not be equallysuccessful in all the states.

Kapoor (2014) discusses how state-level variation in terms of flexibility of labor laws and infrastructure development impacts employment outcomes. The paper mentions that contractualization has been on the rise across all the states. The analysis shows that growth of directly employed workers is higher in flexible states as compared to inflexible states. The paper highlights that the increase in shares of contract workers is larger in inflexible states, while the decline in shares of directly employed workers is smaller in flexible states. Thus it might be the case that labor intensive industries in inflexible states are attempting to meet their labor requirements through increased use of contract labor. The results are shown in Table 12. Inadequate development of physical infrastructure i.e. the poor quality of power supply, road networks and ports and airports are stumbling blocks in the path of the manufacturing sector. The paper discusses how the lack of infrastructural development in certain states hampers employment generation.

\section{Cost Competitiveness and Exports}

Maintaining cost competitiveness is imperative to capture a reasonable share of the export market. It is easy to link the declining wage share with cost compression practices. Kalecki's price fixing equation can be used to understand this.

$$
\begin{aligned}
& \mathrm{p}=(1+\mu)\left(\mathrm{wl}+r_{m}\right) \\
& \text { Dividing by } \mathrm{p} \text { on both sides } 1=(1+\mu)\left(\frac{w}{p} \frac{L}{o}+\frac{r_{m}}{p}\right) \\
& \text { where } \mathrm{p}=\text { per unit price of the good } \\
& \mu=\text { mark up } \\
& \mathrm{wl}=\text { unit labour cost } \\
& r_{m}=\text { per unit raw material cost. }
\end{aligned}
$$

In fixing the price, the firm takes into consideration its average prime costs (cost of materials and wages) and a mark-up. Equation (b) explains how factors like markup, changes in labor productivity, the strength of trade unions and input costs are relevant for the distribution of income between workers and capitalists. For instance, if there is a rise in the firm profit margin, in terms of rising markups, to restore the balance there will be a squeeze on the wage bill or the raw material costs. Shocks to the prices of inputs, either domestic or international will also be passed on to some variable in this equation.

The easiest way to maintain cost competitiveness is to compress wages. Mazumdar (2016) mentions `The effect of low wages on competitiveness can be said to have worked in at least three ways - one being a direct consequence of wage stagnation in the sector and the other two being the benefits of being located in a generally cheap labor economy. First, 
wage stagnation in organized manufacturing has certainly shored up the profitability of Indian manufacturing at internationally competitive prices even in the face of increasing capital and material costs of manufacturing output. Second, in the face of large deficits in infrastructure which tend to increase costs, cheap labor in various supporting activities has served as the alternative means of lowering costs of various supporting activities which have a bearing on manufacturing competitiveness. Finally, the low and stagnant levels of wages in the Indian economy, via their effects on the prices of not-tradeable, have also been the principal basis for preventing India's 'national price level' (ratio of PPP conversion factor to market exchange rate) from catching up even in the face of high inflation. This has helped sustain the rupee exchange rate at a more competitive level than that in other Asian economies (Mazumdar, 2016).

Figure 5 plots the data on the average manufacturing cost index for the year 2014, given by the Boston consultancy group. As shown in the figure India is the second lowest cost competitive exporter after Indonesia. Its cost advantage lies in low labor costs and depreciating the currency. Labor costs have been declining due to strong productivity gains.

Anand et al. (2015) analyze the export basket of India and provide suggestions on which exports should India capitalize on. They find that the Indian export has evolved over time. Within manufacturing exports, a clear shift away from traditional exports can be seen, such as textiles, gems, and leather products, there is a movement towardshigh-tech and medium-tech manufacturing products, such as engineering goods. However, the share of high-tech and medium-tech manufacturing exports in total good exports is substantially lower when compared to China or other Emerging markets. The paper indicates that there is likely to be little scope for India to get any major returns out of the export of low-skill or low-tech products because it is likely to face an incumbency disadvantage relative to China and other low-cost producers in Asia. A better strategy is to develop and diversify the high and medium technology manufacture goods for instance: manufacture of aircraft, motor-vehicles, automobile parts, etc.. This could also translate into better employment outcomes.

Services exported by India are highly sophisticated and complex, comparable to the international standards. Research and development services, deserve a special mention here. Further diversification of these services, enhancing their quality will bring in high incomes.

\section{CONCLUSIONS}

The study using data from different sources and the existing literature arrives at certain conclusions. Firstly, the current status of the manufacturing sector presents several problems in making Make in India a success. Overtime, the absorptive capacity of the sector has tended to decline, which poses serious doubts about the achievability of the aims of the campaign. In such a case exclusive focus on the manufacturing sector looks like a faulty strategy. A better plan will be to identify appropriate manufacturing goods and services that can generate enough employment and usher in growth. Along with this identification Skillingand educating India has become imperative, to make the workforce ready for productive employment opportunities. It seems like a long term solution, but to be able to achieve inclusive growth, the nation needs to start now.

\section{REFERENCES}

1. “What to Make in India? Manufacturing or Services?”, Chapter 7, Economic Survey (2014-15).

2. Amirapu, Amrit\& Subramanian, Arvind, 2014, "Manufacturing Futures”, Business Standard, May 9, 2014.

3. Anand, Rahul, Kochhar, Kalpana\& Mishra, Saurabh, 2015, "Make in India: Which Exports Can Drive the Next Wave of 
Growth?", International Monetary Fund, May 2015.

4. Das, Deb Kusum, Choudhury, Homagni\& Singh, Jaivir, 2015, “Contract Labour (Regulation and Abolition) Act 1970 and Labour Market Flexibility: An Exploratory Assessment of Contract Labour use in India's Formal Manufacturing”, INDIAN COUNCIL FOR RESEARCH ON INTERNATIONAL ECONOMIC RELATIONS, Working Paper 300, June 2015.

5. Das, Kusum Deb \&Sen, Kunal (2015), “Where Have All the Workers Gone? Puzzle of Declining Labour Intensity in Organised Indian Manufacturing”, Economic and Political Weekly, June 6, 2015

6. Dasgupta, Sukti \& Singh, Ajit, 2006, “Manufacturing, Services and Premature Deindustrialization in Developing Countries: A Kaldorian Analysis”, United Nations University: World Institute for Development Economics Research, May 2006.

7. Deshpande, L., A. N Sharma, A. Karan and S Sarkar, 2004, "Liberalization and Labour: Labour Flexibility in Indian Manufacturing”, Institute for Human Development, New Delhi.

8. Dutt, P., 2003, "Labor Market Outcomes and Trade Reforms: The Case of India”, in R. Hasan and D. Mitra (eds.): The Impact of Trade on Labor: Issues, Perspectives, and Experiences from Developing Asia, Amsterdam: Elsevier, 2003.

9. Dutta, P. V.,2007, “Trade Protection and Industry Wages in India”, Industrial and Labor Relations Review, Volume 60, No. 2, Pages 268-285.

10. Fei, J.C.H \& G, Ranis, 1964, "Development of Labour Surplus Economy: Theory and Policy”, Oxford University Press, New York.

11. Goldar, Bishwanasth\& Aggarwal, Suresh Chand, 2010, "In formalization of Industrial Labour in India: Are labour market rigidities and growing import competition to blame?", 6th Annual Conference, Indian Statistical Institute, New Delhi.

12. Green, Russell A., 2014, "Can "Make in India” Make Jobs? The Challenges of Manufacturing Growth and High-Quality Job Creation In India”, James A. Baker III Institute of Public Policy of Rice University, December 15, 2014.

13. Harris, J.R. \& M.P., Todaro, 1970, "Migration, Unemployment and Development: A Two Sector Analysis. American Economic Review, 60 (1), 126-142.

14. Kapoor, Radhicka, 2014, “Creating Jobs in India's Organized Manufacturing Sector”, Indian Council for Research on International Economic Relations, September 2014.

15. Krishnamurty, Jayasankar\& Kumar, Abhay, 2015 "The Demographic dividend: challenges to employment and employability”, Indian Journal of Labour Economics.

16. Lewis, W.A., 1954, "Economic Development and Unlimited Supplies of Labour”, The Manchester School, 22 (2).

17. Mahajan, Kanika, 2012 "Agricultural wages and MNREGA: Exploring the myth", Ideas for India for more evidence based policy.

18. Nagaraj, R, 1994, "Employment and Wages in manufacturing Industries: Trends, Hypothesis and Evidence”, Economic and Political weekly, Volume 29, No. 4, Pages 177 - 186.

19. Nagaraj, R, 2002, “Trade and Labour Market Linkages in India: Evidence and Issues", Working Paper No. 50, East West Centre Working Papers Economic Series, East West Centre, Hawaii, August 2002.

20. Papola, T.S., 2007, "Employment Trends", in KaushikBasu (Ed), The Oxford Companion to Economics in India. Oxford University Press, New Delhi.

21. Rao, K.S. Chalapati \& Dhar, Biswajit, 2016, "The Tenuous Relationship between Make in India and FDI Inflows", Institute for Studies in Industrial Development New Delhi, India, December 2016. 
22. Roy, Satyaki, 2012, "CHANGING FACTOR INCOMES IN INDUSTRIES AND OCCUPATIONS Review of Long Term Trends", ISID.

23. Sasikumar, S.K. \&Thimothy, Rakkee, 2013, "Surmounting India's Employment Challenge: Evidence from NSSO Data (200405 to 2011-12)”, Labour and Development, V.V. Giri National Labour Institute, Volume 20, No.1, June 2013.

24. Sharma, A. N.,2006, “Flexibility, Employment and Labour Market Reforms in India”, Economic and Political Weekly, Volume 41, No. 21, Pages 2078 - 2085.

25. Shaw, Abhishek, 2013, "Employment Trends in India An Overview of NSSO's 68th Round", Economic \& Political Weekly, October 19, 2013.

26. Srija, A. \&Shirke, Shrinivas V., 2014 "An Analysis of the Informal Labour Market in India”, Confederation of Indian Industry, September-October 2014.

\section{APPENDIX}

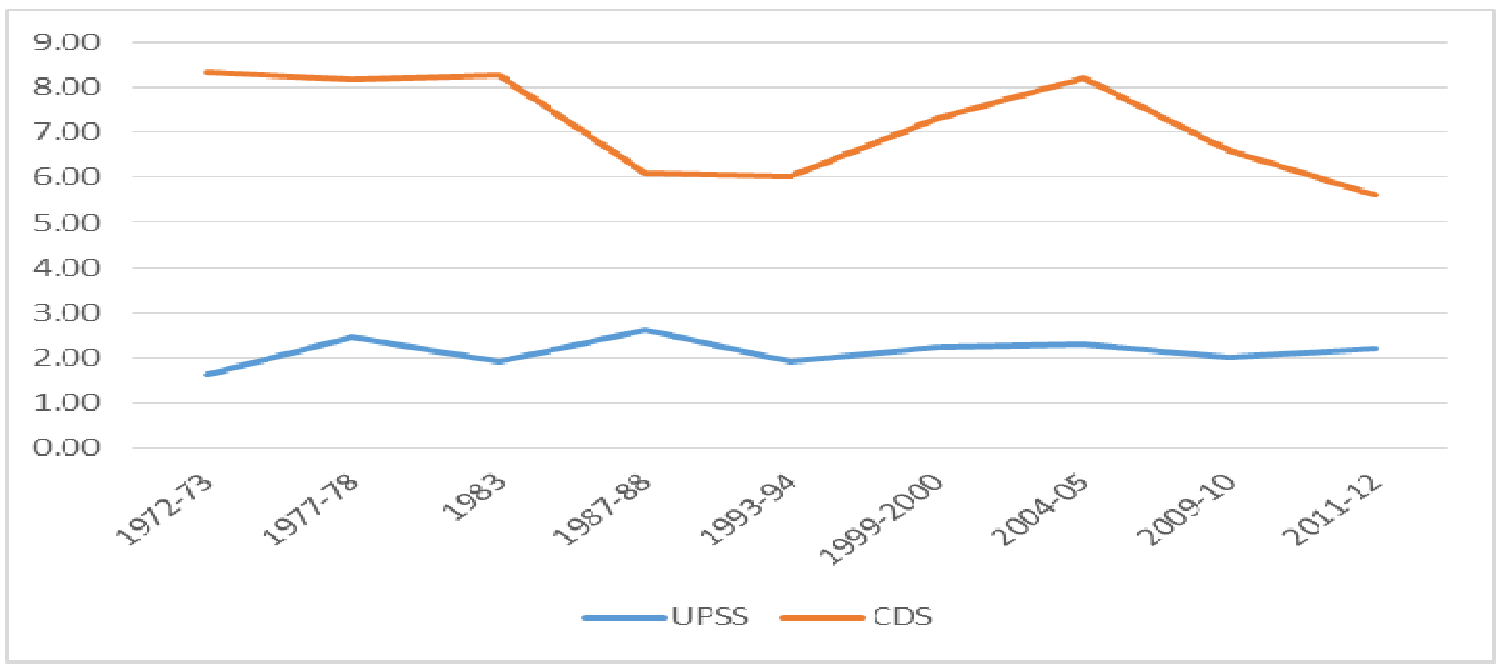

Figure 1: Unemployment Rate (\% of Labor Force)

Source: Papola (2007) \& Shaw (2013).

Table 1: Sectoral Break-Up of Employment (\%)

\begin{tabular}{|l|c|c|c|}
\hline \multicolumn{1}{|c|}{ Sector } & $\mathbf{2 0 0 4 - 0 5}$ & $\mathbf{2 0 0 9 - 1 0}$ & $\mathbf{2 0 1 1 - 1 2}$ \\
\hline Primary & 58.5 & 53.2 & 48.9 \\
\hline Secondary & 18.5 & 21.5 & 24.3 \\
\hline Services & 23.4 & 25.3 & 26.8 \\
\hline
\end{tabular}

Source: $61 \mathrm{st}, 66$ th, and 68 th NSSO rounds.

Table 2: 2004-05, Proportion of Formal and Informal Employment at the Sectoral Level (\%)

\begin{tabular}{|l|c|c|c|c|c|}
\hline \multicolumn{1}{|c|}{ 2004-05 } & \multicolumn{2}{c|}{ Organized Sector } & \multicolumn{2}{c|}{ Unorganized Sector } & Total \\
\hline & Formal & Informal & Formal & Informal & \\
\hline Agriculture & 0.76 & 0.99 & 0.00 & 56.75 & 58.50 \\
\hline Manufacturing & 1.21 & 2.10 & 0.10 & 8.33 & 11.73 \\
\hline Non-Manufacturing & 0.53 & 1.45 & 0.00 & 4.42 & 6.41 \\
\hline Services & 4.48 & 1.89 & 0.19 & 16.80 & 23.36 \\
\hline \multicolumn{1}{|c|}{ Total } & $\mathbf{6 . 9 8}$ & $\mathbf{6 . 4 3}$ & $\mathbf{0 . 2 9}$ & $\mathbf{8 6 . 3 0}$ & $\mathbf{1 0 0 . 0 0}$ \\
\hline
\end{tabular}

Source: Srija\&Shirke (2014) 
Table 3: 2011-12, Proportion of Formal and Informal Employment at the Sectoral Level (\%)

\begin{tabular}{|l|c|c|c|c|c|}
\hline \multicolumn{1}{|c|}{$\mathbf{2 0 1 1 - 1 2}$} & \multicolumn{2}{|c|}{ Organized Sector } & \multicolumn{2}{c|}{ Unorganized Sector } & Total \\
\hline & Formal & Informal & Formal & Informal & \\
\hline Agriculture & 0.06 & 0.16 & 0.00 & 48.69 & 48.90 \\
\hline Manufacturing & 1.48 & 2.79 & 0.06 & 8.28 & 12.60 \\
\hline Non-Manufacturing & 0.69 & 3.77 & 0.01 & 7.18 & 11.65 \\
\hline Services & 5.62 & 2.72 & 0.22 & 18.29 & 26.84 \\
\hline \multicolumn{1}{|c|}{ Total } & $\mathbf{7 . 8 4}$ & $\mathbf{9 . 4 3}$ & $\mathbf{0 . 2 9}$ & $\mathbf{8 2 . 4 3}$ & $\mathbf{1 0 0 . 0 0}$ \\
\hline
\end{tabular}

Source: Srija\&Shirke (2014)

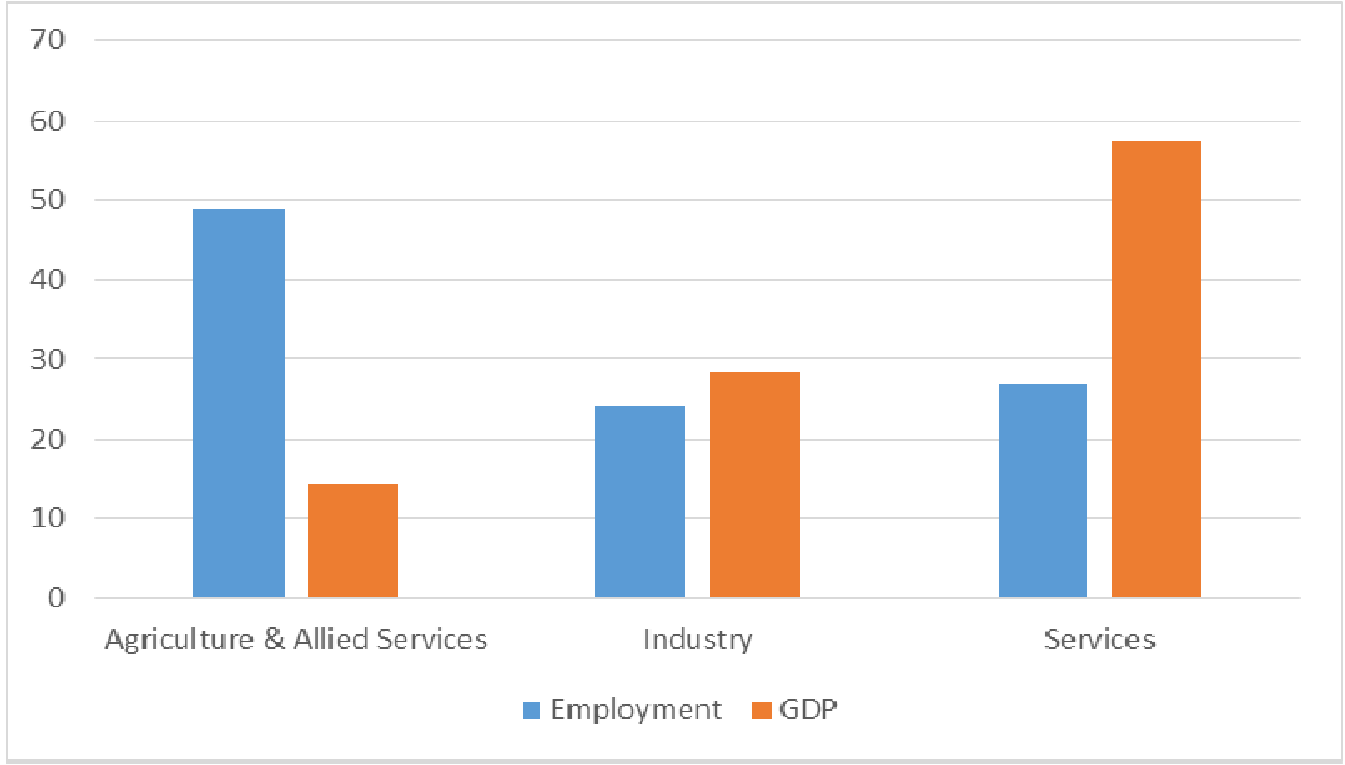

Figure 2: Sectoral Contribution to Employment and GDP (2011-12)

Source: MOSPI \& NSSO68th round

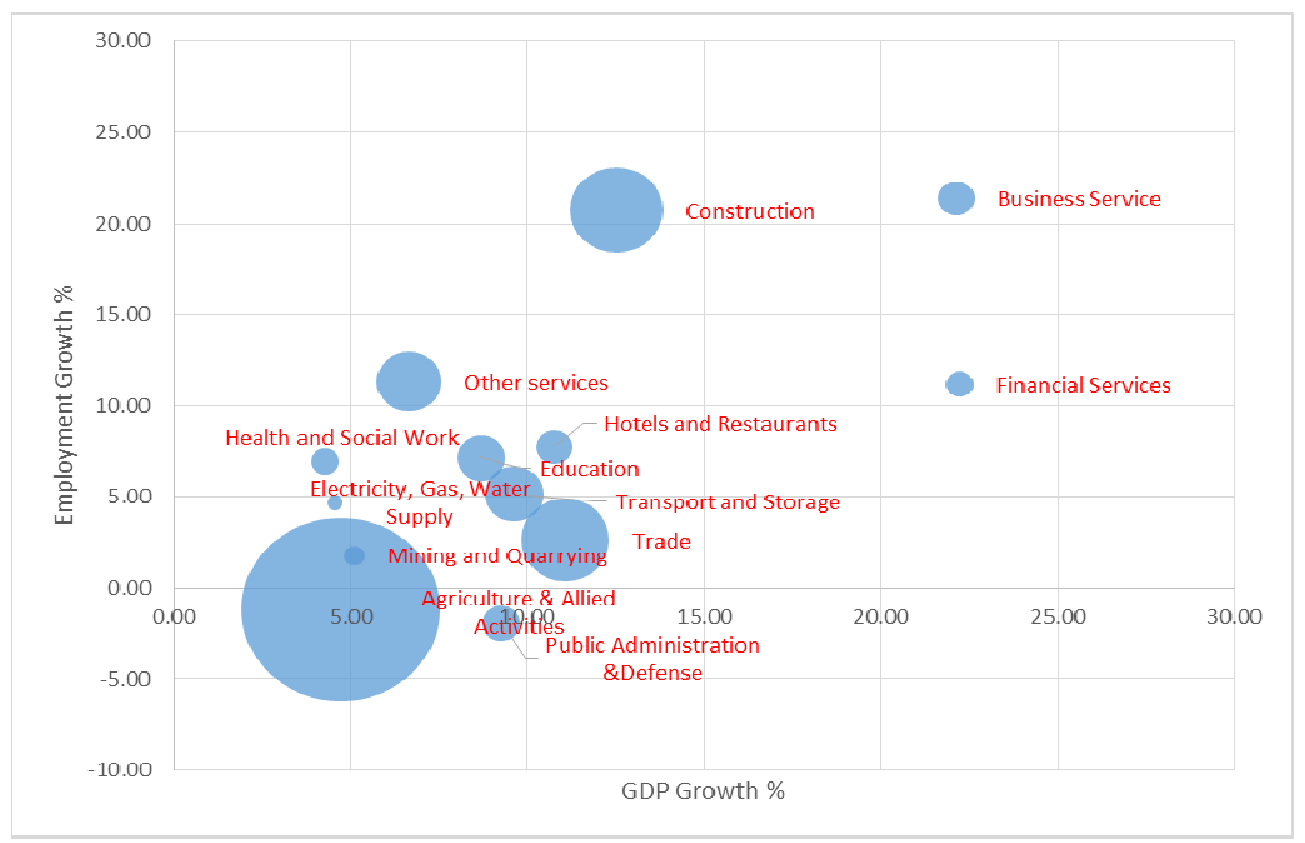

Figure 3: Performance of Various Sub-Sectors in Agriculture, Services and Non-Manufacturing (AAGR \%) 2004-05 to 2011-12

Source: Wold KLEMS 
Table 4: Employment and GDP Growth Rate for Various Manufacturing Sub-Sectors for the Period 2004-05 to 2011-12

\begin{tabular}{|l|c|c|c|}
\hline \multicolumn{1}{|c|}{ KLEMS Industry Description } & $\begin{array}{c}\text { Employment } \\
\text { Growth }\end{array}$ & GDP Growth & $\begin{array}{c}\text { Employment } \\
\text { Share }\end{array}$ \\
\hline Food Products, Beverages and Tobacco & 1.21 & 12.93 & 2.37 \\
\hline Textiles, Textile Products, Leather and Footwear & 0.87 & 12.47 & 2.86 \\
\hline Wood and Products of wood & -2.84 & 13.60 & 0.81 \\
\hline Pulp, Paper, Paper products, Printing and Publishing & 1.73 & 12.37 & 0.33 \\
\hline Coke, Refined Petroleum Products and Nuclear fuel & -1.81 & 15.27 & 0.03 \\
\hline Chemicals and Chemical Products & 0.66 & 15.79 & 0.43 \\
\hline Rubber and Plastic Products & 2.77 & 19.48 & 0.24 \\
\hline Other Non-Metallic Mineral Products & 4.34 & 14.53 & 1.04 \\
\hline Basic Metals and Fabricated Metal Products & 3.52 & 16.98 & 0.95 \\
\hline Machinery, nec. & 6.48 & 23.14 & 0.40 \\
\hline Electrical and Optical Equipment & 4.91 & 20.47 & 0.35 \\
\hline Transport Equipment & 16.15 & 16.96 & 0.34 \\
\hline Manufacturing, nec; recycling & 8.64 & 15.08 & 1.26 \\
\hline
\end{tabular}

Source: World KLEMS

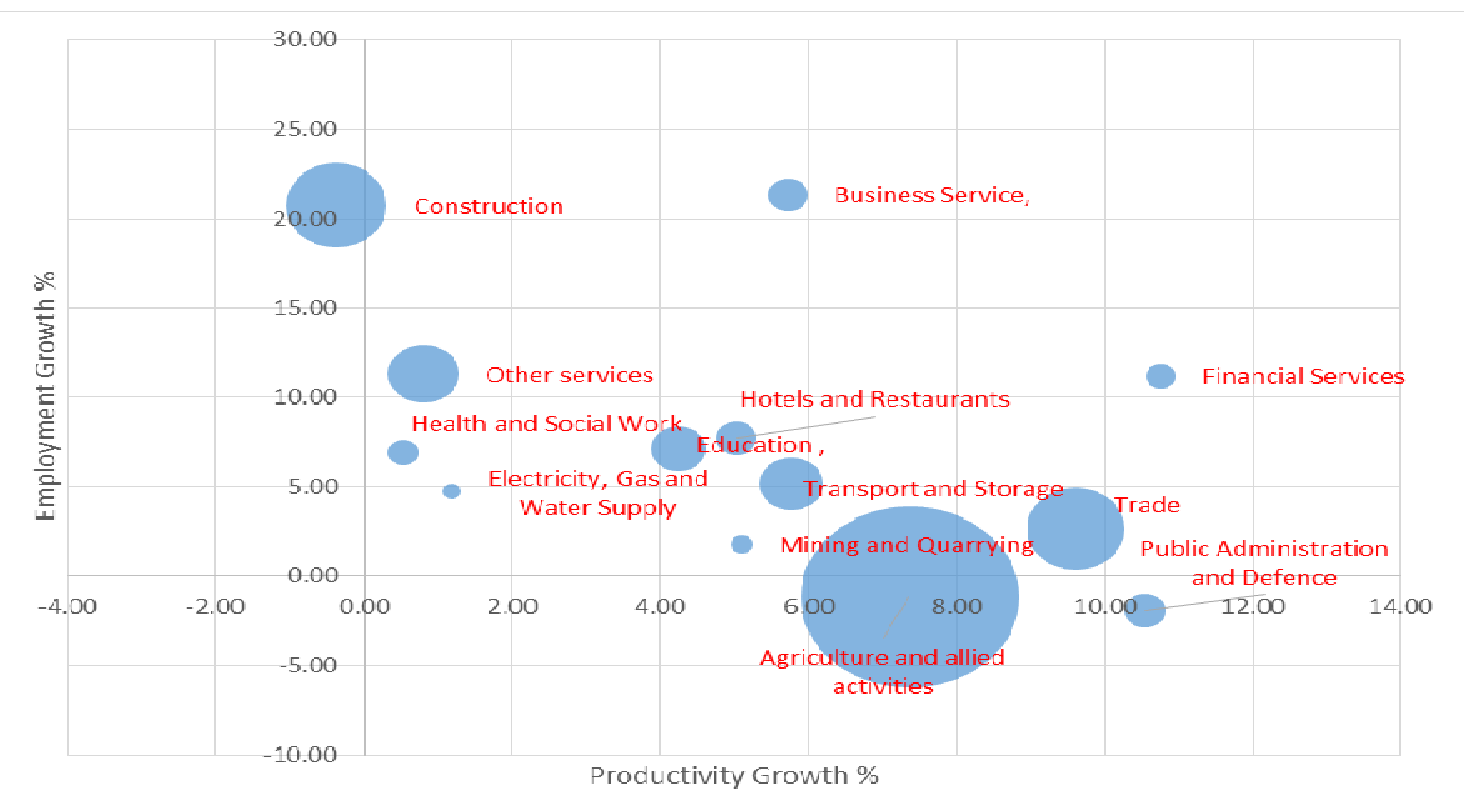

Figure 4: Productivity and Employment Growth in Various Sub-Sectors in Agriculture, Services and Non-Manufacturing (AAGR \%) 2004-05 to 2011-12

Source: World KLEMS

Table 5: Employment and Productivity Growth of Various Sub-Sectors in Manufacturing for the Period 2004-05 to 2011-12

\begin{tabular}{|l|c|c|c|}
\hline \multicolumn{1}{|c|}{ KLEMS Industry } & $\begin{array}{c}\text { Productivity } \\
\text { Growth }\end{array}$ & Employment Growth & $\begin{array}{c}\text { Employment } \\
\text { Share }\end{array}$ \\
\hline Food Products, Beverages and Tobacco & 10.79 & 1.21 & 2.37 \\
\hline $\begin{array}{l}\text { Textiles, Textile Products, Leather and } \\
\text { Footwear }\end{array}$ & 15.82 & 0.87 & 2.86 \\
\hline Wood and Products of wood & 23.64 & -2.84 & 0.81 \\
\hline $\begin{array}{l}\text { Pulp, Paper, Paper products, Printing } \\
\text { and Publishing }\end{array}$ & 13.60 & 1.73 & 0.33 \\
\hline $\begin{array}{l}\text { Coke, Refined Petroleum Products and } \\
\text { Nuclear fuel }\end{array}$ & 10.95 & -1.81 & 0.03 \\
\hline
\end{tabular}




\begin{tabular}{|l|c|c|c|}
\hline \multicolumn{4}{|c|}{ Table 5: Contd., } \\
\hline Chemicals and Chemical Products & 17.06 & 0.66 & 0.43 \\
\hline Rubber and Plastic Products & 10.79 & 2.77 & 0.24 \\
\hline Other Non-Metallic Mineral Products & 11.71 & 4.34 & 1.04 \\
\hline $\begin{array}{l}\text { Basic Metals and Fabricated Metal } \\
\text { Products }\end{array}$ & 11.99 & 3.52 & 0.95 \\
\hline Machinery, nec. & 13.36 & 6.48 & 0.40 \\
\hline Electrical and Optical Equipment & 10.68 & 4.91 & 0.35 \\
\hline Transport Equipment & 6.87 & 16.15 & 0.34 \\
\hline Manufacturing, nec; recycling & 8.58 & 8.64 & 1.26 \\
\hline
\end{tabular}

Source: World KLEMS

Table 6: Informal Employment in the Non-Agriculture Sector (In Million)

\begin{tabular}{|l|c|c|}
\hline \multicolumn{1}{|c|}{ Non-Agriculture Sector } & $\mathbf{2 0 0 4 - 0 5}$ & $\mathbf{2 0 1 1 - 1 2}$ \\
\hline Mining & 1.82 & 1.79 \\
\hline Manufacturing & 47.92 & 52.49 \\
\hline Electricity \& Water Supply & 0.24 & 1.21 \\
\hline Construction & 24.94 & 48.92 \\
\hline Trade, Hotel \& Restaurant & 46.02 & 50.17 \\
\hline Transportation, Storage \& Communications & 14.66 & 18.02 \\
\hline Real estate other business activities & 3.43 & 5.02 \\
\hline Education & 5.15 & 6.31 \\
\hline Finance & 1.13 & 1.81 \\
\hline Health & 2.1 & 2.68 \\
\hline Public Administration, defence & 1.17 & 1.11 \\
\hline Other Services & 12.26 & 14.5 \\
\hline
\end{tabular}

Source: Srija\&Shirke (2014)

Table 7: Distribution of Self-Employed, Casual and Regular Workers

\begin{tabular}{|c|c|c|c|c|c|c|}
\hline \multirow[b]{2}{*}{ KLEMS Industry Description } & \multicolumn{2}{|c|}{ Self Employed } & \multicolumn{2}{|c|}{ Casual Workers } & \multicolumn{2}{|c|}{ Regular Workers } \\
\hline & 2004-05 & 2011-12 & $2004-05$ & 2011-12 & 2004-05 & 2011-12 \\
\hline Agriculture,Hunting,Forestry and Fishing & 63.89 & 64.55 & 35.02 & 34.60 & 1.10 & 0.85 \\
\hline Mining and Quarrying & 10.33 & 6.00 & 45.46 & 56.27 & 44.21 & 37.74 \\
\hline Food Products,Beverages and Tobacco & 54.70 & 64.68 & 26.53 & 13.85 & 18.77 & 21.47 \\
\hline Textiles, Textile Products, Leather and Footwear & 53.49 & 44.88 & 14.86 & 16.50 & 31.65 & 38.62 \\
\hline Wood and Products of wood & 77.66 & 70.41 & 15.88 & 21.86 & 6.46 & 7.73 \\
\hline Pulp, Paper,Paper products,Printing and Publishing & 30.92 & 30.28 & 8.57 & 8.21 & 60.51 & 61.51 \\
\hline Coke, Refined Petroleum Products and Nuclear fuel & 11.76 & 5.03 & 14.86 & 14.60 & 73.38 & 80.37 \\
\hline Chemicals and Chemical Products & 22.09 & 12.41 & 17.94 & 11.42 & 59.97 & 76.17 \\
\hline Rubber and Plastic Products & 18.16 & 14.51 & 13.47 & 8.50 & 68.37 & 76.99 \\
\hline Other Non-Metallic Mineral Products & 43.02 & 24.01 & 38.67 & 54.40 & 18.32 & 21.59 \\
\hline Basic Metals and Fabricated Metal Products & 28.14 & 27.19 & 25.70 & 16.75 & 46.15 & 56.06 \\
\hline Machinery, nec. & 24.68 & 29.22 & 12.06 & 5.67 & 63.26 & 65.11 \\
\hline Electrical and Optical Equipment & 26.17 & 20.29 & 6.26 & 5.13 & 67.57 & 74.58 \\
\hline Transport Equipment & 7.52 & 11.03 & 10.02 & 6.64 & 82.47 & 82.33 \\
\hline Manufacturing, nec; recycling & 58.26 & 52.86 & 13.92 & 14.51 & 27.82 & 32.64 \\
\hline Electricity, Gas and Water Supply & 2.47 & 2.46 & 13.08 & 6.12 & 84.45 & 91.42 \\
\hline Construction & 30.83 & 10.92 & 62.17 & 83.49 & 7.01 & 5.58 \\
\hline Trade & 73.63 & 76.19 & 10.36 & 5.22 & 16.02 & 18.60 \\
\hline Hotels and Restaurants & 63.48 & 59.13 & 8.86 & 11.64 & 27.66 & 29.23 \\
\hline Transport and Storage & 46.46 & 44.48 & 14.63 & 15.27 & 38.91 & 40.25 \\
\hline Post and Telecommunication & 27.26 & 13.01 & 8.82 & 4.36 & 63.91 & 82.64 \\
\hline Financial Services & 23.58 & 24.57 & 1.11 & 1.04 & 75.31 & 74.40 \\
\hline Business Service & 50.14 & 29.67 & 3.90 & 4.43 & 45.97 & 65.90 \\
\hline Public Administration and Defense; Compulsory Social Security & 0.49 & 0.00 & 3.24 & 0.89 & 96.27 & 99.11 \\
\hline Education & 15.97 & 11.10 & 1.15 & 0.77 & 82.89 & 88.13 \\
\hline Health and Social Work & 29.05 & 27.65 & 2.28 & 2.74 & 68.67 & 69.62 \\
\hline Other services & 58.49 & 59.52 & 9.45 & 10.76 & 32.06 & 29.73 \\
\hline
\end{tabular}

Source: World KLEMS 
Table 8: Real Wage and Yield Growth (CAGR \%)

\begin{tabular}{|c|c|c|c|c|c|c|}
\hline State & $\begin{array}{c}\text { Real Wage } \\
\text { Rate Male } \\
(1999-2004)\end{array}$ & $\begin{array}{c}\text { Real Wage } \\
\text { Rate Male } \\
(2004-2009)\end{array}$ & $\begin{array}{l}\text { Real Wage } \\
\text { Female } \\
(1999-2004)\end{array}$ & $\begin{array}{l}\text { Real Wage } \\
\text { Female } \\
(2004-2009)\end{array}$ & $\begin{array}{l}\text { Food Grain } \\
\text { Yield } \\
(1999-2004)\end{array}$ & $\begin{array}{c}\text { food Grain } \\
\text { Yield } \\
(2004-2009)\end{array}$ \\
\hline Andhra Pradesh & 0.4 & 7.9 & -0.2 & 10.4 & 0.9 & 5.5 \\
\hline Assam & 4.9 & 0 & 7.9 & -0.4 & 1.4 & 1.4 \\
\hline Bihar & 2.5 & 1.8 & 2.5 & 1.9 & -2.7 & 3.2 \\
\hline Gujarat & 1.1 & 1.1 & 1.4 & 1.9 & 0.7 & 3.7 \\
\hline Haryana & 1.4 & 0.7 & -0.2 & -0.6 & 1.8 & 1.9 \\
\hline Karnataka & 0.9 & 4.4 & 1.2 & 4.1 & -2.7 & 6.2 \\
\hline Kerela & 1.2 & 1.1 & -0.1 & 5.4 & 1.6 & 2.3 \\
\hline Madhya Pradesh & 2.2 & 3.8 & 1.7 & 5.2 & -0.5 & 1.6 \\
\hline Maharashtra & 0.6 & 1.9 & -0.1 & 4.7 & -0.7 & 4.7 \\
\hline Orissa & 7.1 & 2.9 & 5.1 & 4 & 0.2 & 4.9 \\
\hline Punjab & -0.2 & 1.9 & -2.7 & 0.5 & 0.7 & 1.4 \\
\hline Rajasthan & 3.1 & 1.9 & 3.5 & 3 & 1.4 & 1.3 \\
\hline Tamil Nadu & 1.8 & 3.8 & 0.3 & 5.9 & -6.8 & 6.3 \\
\hline Uttar Pradesh & 3 & 2.5 & 4.2 & 0.2 & -0.8 & 2 \\
\hline West Bengal & -0.3 & 4 & -0.4 & 3.5 & 2.1 & 0.7 \\
\hline All India & 1.8 & 3.1 & 1.2 & 5 & 0.1 & 2.5 \\
\hline
\end{tabular}

Source: Mahajan (2012)

Table 9: Trend Growth Rate in the Capital Intensity of Production by Industry (2000-01 to 2010-11), NIC 2004

\begin{tabular}{|c|c|c|c|}
\hline \multicolumn{2}{|c|}{ Labour Intensive Industries } & \multicolumn{2}{|c|}{ Capital Intensive Industries } \\
\hline NIC & Trend Growth (\%) & NIC & Trend growth (\%) \\
\hline 152 & 5.77 & 151 & 3.47 \\
\hline 153 & 9.19 & 155 & 2.56 \\
\hline 154 & 4.18 & 171 & 4.91 \\
\hline 160 & 4.41 & 210 & 7.25 \\
\hline 172 & 3.64 & 221 & 11.13 \\
\hline 173 & 1.71 & 223 & -2.21 \\
\hline 181 & 1.47 & 231 & 8.97 \\
\hline 182 & 16.89 & 232 & 1.10 \\
\hline 191 & 2.27 & 241 & 9.74 \\
\hline 192 & 0.48 & 242 & 6.29 \\
\hline 201 & 11.81 & 243 & 3.19 \\
\hline 202 & 5.78 & 251 & 3.29 \\
\hline 222 & 9.42 & 252 & 0.84 \\
\hline 273 & 10.74 & 261 & 1.78 \\
\hline 281 & 10.45 & 269 & 1.53 \\
\hline 289 & 4.44 & 271 & 5.01 \\
\hline 291 & 4.77 & 272 & 7.60 \\
\hline 292 & 4.34 & 293 & 2.00 \\
\hline 311 & 5.99 & 300 & 2.49 \\
\hline 312 & 4.27 & 313 & 3.57 \\
\hline 315 & -1.84 & 314 & 1.52 \\
\hline 331 & -3.73 & 319 & 1.89 \\
\hline 333 & -8.92 & 321 & -7.14 \\
\hline 342 & 2.57 & 322 & 8.96 \\
\hline 351 & 24.72 & 323 & 5.65 \\
\hline 352 & 7.84 & 332 & 1.26 \\
\hline 361 & -0.25 & 341 & 2.52 \\
\hline 369 & -5.41 & 343 & 3.47 \\
\hline & & 353 & 8.49 \\
\hline & & 359 & 1.35 \\
\hline
\end{tabular}


Source: Kapoor (2014)

Table 10: Number of Workers Per Factory Labour Intensive Industries

\begin{tabular}{|c|c|c|c|c|}
\hline NIC-98 & $\begin{array}{c}\mathbf{1 9 8 0 - 8 1} \text { to } \\
\mathbf{1 9 9 0 - 9 1}\end{array}$ & $\begin{array}{c}\mathbf{1 9 9 1 - 9 2} \text { to } \\
\mathbf{1 9 9 9 - 2 0 0 0}\end{array}$ & $\begin{array}{c}\mathbf{2 0 0 0 - 0 1} \text { to } \\
\mathbf{2 0 0 9 - 1 0}\end{array}$ & $\begin{array}{c}\mathbf{1 9 8 0 - 8 1} \text { to } \\
\mathbf{2 0 0 9 - 1 0}\end{array}$ \\
\hline 153 & 19 & 20 & 19 & 19 \\
\hline 154 & 100 & 98 & 93 & 97 \\
\hline 160 & 46 & 89 & 147 & 93 \\
\hline 173 & 20 & 27 & 65 & 37 \\
\hline 181 & 43 & 64 & 116 & 74 \\
\hline 182 & 19 & 34 & 65 & 39 \\
\hline 191 & 43 & 35 & 41 & 40 \\
\hline 192 & 61 & 60 & 80 & 67 \\
\hline 201 & 9 & 7 & 6 & 8 \\
\hline 202 & 31 & 25 & 19 & 25 \\
\hline 352 & 638 & 459 & 69 & 394 \\
\hline 361 & 27 & 23 & 30 & 26 \\
\hline 369 & 26 & 44 & 68 & 46 \\
\hline
\end{tabular}

Source: Sen\& Das (2014)

Table 11: Projected Age Wise Labour Force in India in 2026 and their Proportions in Total Labour Force

\begin{tabular}{|l|c|c|c|c|c|c|c|c|c|c|c|c|}
\hline \multicolumn{1}{|c|}{ State } & \multicolumn{9}{|c|}{ in millions } & \multicolumn{6}{c|}{ in \% } \\
\hline & $\mathbf{0 - 1 4}$ & $\mathbf{1 5 - 2 9}$ & $\mathbf{3 0 - 5 9}$ & $\mathbf{1 5 - 5 9}$ & $\mathbf{6 0 +}$ & Total & $\mathbf{0 - 1 4}$ & $\mathbf{1 5 - 2 9}$ & $\mathbf{3 0 - 5 9}$ & $\mathbf{1 5 - 5 9}$ & $\mathbf{6 0 +}$ & Total \\
\hline Andhra Pradesh & 0.2 & 12.7 & 31.9 & 44.6 & 5.6 & 50.3 & 0.3 & 25.2 & 63.4 & 88.6 & 11.1 & 100 \\
\hline Assam & 0 & 4.6 & 8.2 & 12.8 & 1 & 13.8 & 0.2 & 33 & 59.6 & 92.6 & 7.2 & 100 \\
\hline Bihar & 0.1 & 14.7 & 19.8 & 34.6 & 4.6 & 39.3 & 0.4 & 37.5 & 50.5 & 88 & 11.6 & 100 \\
\hline Chattisgarh & 0 & 4.8 & 8.5 & 13.3 & 1.4 & 14.7 & 0.3 & 32.6 & 57.9 & 90.5 & 9.2 & 100 \\
\hline Gujrat & 0.2 & 8.9 & 19.9 & 28.9 & 2.9 & 31.9 & 0.5 & 28 & 62.4 & 90.4 & 9.1 & 100 \\
\hline Haryana & 0 & 3.6 & 8.4 & 12 & 0.9 & 12.9 & 0.1 & 27.6 & 65.4 & 92.9 & 7 & 100 \\
\hline Himachal Pradesh & 0 & 1 & 3 & 4 & 0.6 & 4.6 & 0.1 & 22.1 & 66.5 & 87.6 & 12.4 & 100 \\
\hline J\& K & 0 & 1.8 & 3.8 & 5.5 & 0.6 & 6.1 & 0.2 & 28.8 & 61.2 & 90 & 9.8 & 100 \\
\hline Jharkhand & 0.1 & 5.5 & 8.6 & 14.1 & 1.7 & 15.9 & 0.9 & 34.5 & 54 & 88.4 & 10.7 & 100 \\
\hline Karnataka & 0.1 & 7.8 & 20.1 & 28 & 3.3 & 31.4 & 0.3 & 24.9 & 64.1 & 89 & 10.7 & 100 \\
\hline Kerela & 0 & 3.2 & 11.1 & 14.3 & 2.1 & 16.4 & 0 & 19.4 & 68 & 87.4 & 12.6 & 100 \\
\hline Madhya Pradesh & 0.1 & 12.7 & 21.8 & 34.5 & 3.5 & 38.1 & 0.2 & 33.5 & 57.2 & 90.6 & 9.1 & 100 \\
\hline Maharastra & 0.2 & 16.5 & 42.5 & 59 & 5.4 & 64.6 & 0.3 & 25.5 & 65.9 & 91.3 & 8.4 & 100 \\
\hline Oddisha & 0.1 & 6.6 & 12.9 & 19.5 & 2.1 & 21.7 & 0.4 & 30.3 & 59.7 & 90 & 9.6 & 100 \\
\hline Punjab & 0 & 3.8 & 9.2 & 13 & 1.5 & 14.5 & 0.3 & 26.5 & 63.2 & 89.7 & 10 & 100 \\
\hline Rajasthan & 0.2 & 13.3 & 21.9 & 35.2 & 3.8 & 39.2 & 0.4 & 34 & 55.8 & 55.8 & 89.8 & 100 \\
\hline Tamil Nadu & 0 & 7 & 24 & 31 & 4.4 & 35.4 & 0.1 & 19.9 & 67.7 & 87.6 & 12.3 & 100 \\
\hline Uttar Pradesh & 0.9 & 35.2 & 52.6 & 87.8 & 11.3 & 100.1 & 0.9 & 35.2 & 52.5 & 87.8 & 11.3 & 100 \\
\hline Utrakhand & 0 & 1.5 & 3.2 & 4.8 & 0.3 & 5.1 & 0.4 & 29.9 & 63 & 92.9 & 6.7 & 100 \\
\hline West Bengal & 0.4 & 13.8 & 28 & 41.8 & 4 & 46.1 & 0.8 & 29.9 & 60.7 & 91.7 & 7.6 & 100 \\
\hline India & 2.8 & 187.6 & 377.5 & 565.1 & 58.9 & 626.8 & 0.5 & 29.9 & 60.2 & 90.2 & 9.4 & 100 \\
\hline
\end{tabular}

Source: Krishnamurty\& Kumar (2015)

Table 12: Comparison of Growth Rate of Workers According to the State/Industry Characteristic

\begin{tabular}{|l|l|c|}
\hline \multicolumn{1}{|c|}{ State/Industry Characteristic } & \multicolumn{1}{c|}{ Workers } & Growth Rate (2000-10) \\
\hline All States & Directly Employed Workers & 3.66 \\
\hline & Contract Workers & 13.7 \\
\hline Flexible States & Directly Employed Workers & 4.95 \\
\hline & Contract Workers & 15.38 \\
\hline Inflexible States & Directly Employed Workers & 0.63 \\
\hline & Contract Workers & 10.67 \\
\hline
\end{tabular}




\begin{tabular}{|l|l|c|}
\hline \multicolumn{3}{|c|}{ Table 12: Contd., } \\
\hline Labour Intensive Industries in Flexible States & Directly Employed Workers & 15.36 \\
\hline Labour Intensive Industries in Inflexible States & Contract Workers & 2.69 \\
\hline & Directly Employed Workers & 10.54 \\
\hline
\end{tabular}

Source: Kapoor (2014)

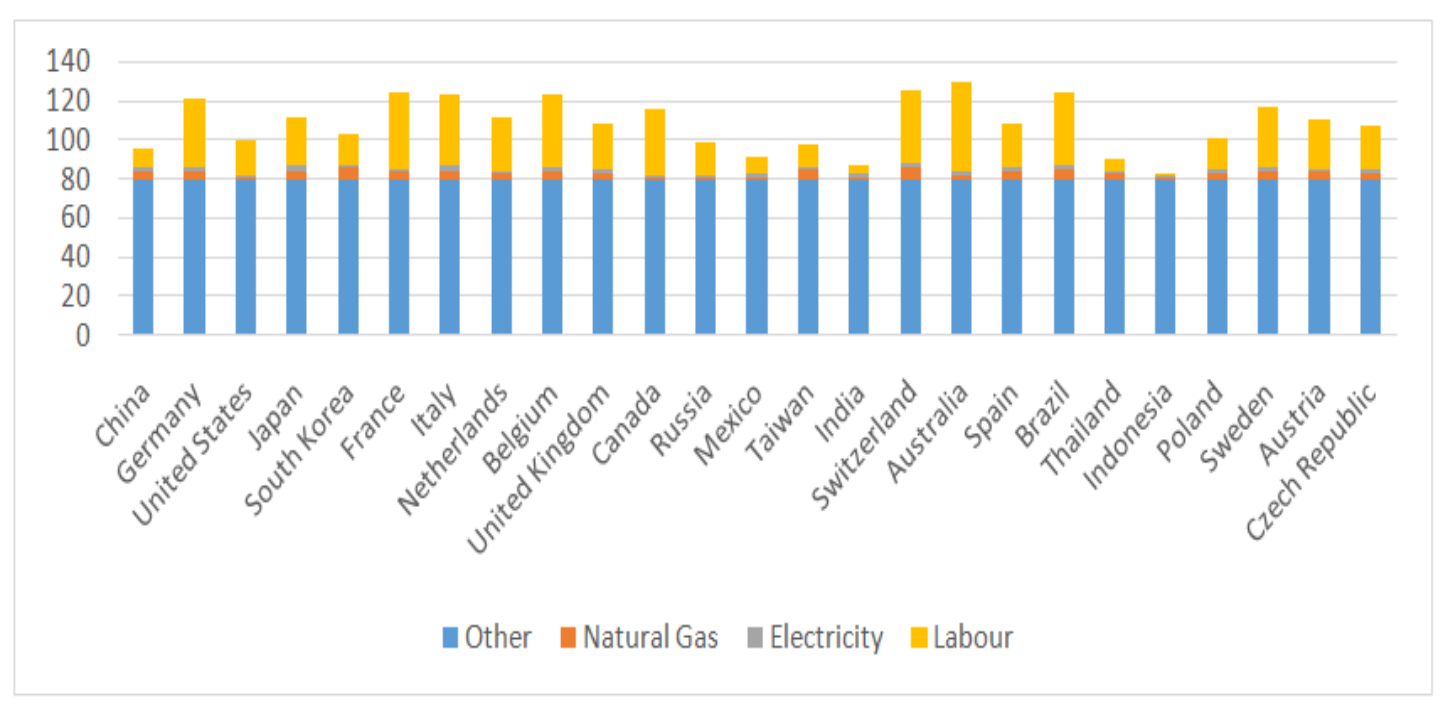

Figure 5: Average Manufacturing Cost Index 2014

Source: The Boston Consultancy Group 
